14. U.S. Department of Education (2015) White House Initiativeon Historically Black College sand Universities. [Online] Available from: https://sites.ed.gov/whhbcu/. [Accessed: 28 $8^{\text {th }}$ October 2017].

15. Thought Co. Lifelong learning (2017) Phi Beta Kappa Honor Society. [Online] Available from: https://goo.gl/DxGf7r. [Accessed: $1^{\text {st }}$ October 2017].

16. GREELEY, M.A. (1977). The Changing Catholic College. New Brunswick.

17.The National Academies of Sciences, Engineering, and Medicine (2017) Ford Foundation Fellowship Programs. [Online] Available from: https://goo.gl/8VTZoz. [Accessed: $1^{\text {st }}$ October 2017].

18.Hoover Institution (2014) Condoleezza Rice. [Online] Available from: https://www.hoover.org/profiles/condoleezza-rice. [Accessed: $2^{\text {nd }}$ October 2017].

19.NBC News (2005) Rice sworn in as a secretary of state. [Online] Available from: https://goo.gl/yxSf8S. [Accessed: $5^{\text {th }}$ October 2017].

Надійшла до редколегії 13.03.2018

Olena Petrauskas, Engineer I-st Category Department of History of International Relations and foreign policy, Institute of History of Ukraine, National Academy of Sciences of Ukraine.

\title{
CONDOLEEZZA RICE. THE WAY TO THE POLITICAL OLYMPUS.
}

Abstract. The article examines the career of Condoleezza Rice in the context of the solution of the African-American issue in the United States. Also characterizes the starting positions and individual qualities of the future Secretary of State. The article determines the role of the family and the peculiarities of upbringing and shaping the views and life orientations of Mrs. Rice. Also highlights the socio-political conditions and circumstances of professional development of the Secretary of State. In particular, the article focuses is on the situation of the African-American population 1960-1970's. Allocate and analyze the main factors influencing the choice of profession by Condoleezza Rice. Characterizes the main stages of $C$. Rice's academic and political career in the context of "positive discrimination" and quota programs. The reasons for changing political views are Condoleezza Rice is highlighted. The article analyzes the individual experience in the realization of social opportunities for African Americans, which arose as a result of the adoption of anti-discrimination legislation in the United States and changes in the targeted state policy to overcome the problems of racial relations. The article determines the changes in the socio-political situation of African Americans in the second half of the twentieth century.

Keywords: African Americans in the United States, socio-political situation, integration, anti-discrimination policy, US Secretary of State Condoleezza Rice.

\section{УДК 94 (73)}

http://doi.org/10.17721/2521-1706.2018.05.140-152

Ігор Римар, аспірант, Національний педагогічний університет імені М. П. Драгоманова, м. Київ

\section{III ІНТЕРНАЦІОНАЛ ТА КОМУНІСТИЧНА ПАРТІЯ США: ПОЛІТИКА ТА ВЗАЕМОВІДНОСИНИ (СЕРПЕНЬ 1939 - ЧЕРВЕНЬ 1941 РОКУ)}

\footnotetext{
Анотація. На основі документів та монографічної літератури дано характеристику політииі Комуністичної партії США та проведено аналіз ї̈ взаємовідносин з ІІІ Інтернаціоналом в рамках рецесивної тактико - стратегічної моделі протягом серпня 1939 - червня 1941 року.
} 
Головна увага приділена реакції очевидичв подій, насамперед членів Комуністичної партії США, на підписання пакту Молотова - Ріббентропа 23 серпня 1939 року. Проаналізовано ставлення генерального секретаря Комуністичної партії США Е. Браудера, як до самого пакту, так і до зовнішньополітичної лінії, яку проводив СРСР та III Інтернаціонал протягом серпня 1939 - червня 1941 року.

Знаходячись на периферії інтересів Секретаріату III Інтернаціоналу, Комуністична партія США підтримувала та відстоювала тезу про «імперіалістичний» характер війни, причетність урядів, насамперед Британії та Франиії, а також адміністрації Ф. Рузвельта, до ї̈ продовження та затягування, переростання у світову війну. Це призвело до стрімкої втрати електорату та підтримки американським суспільством, яку Комуністична партія здобула за період проведення політики народного фронту, протягом другої половини 1930-х років. Окрема увага приділена позииї Комуністичної партї США щчодо радянсько-фінської війни 1939 - 1940 року.

Здійснено аналіз Акту Вурхіса 1940 року, його впливу на становище Комуністичної партії США, а також проблемі існування III Інтернаціоналу, як організації міжнародного комуністичного руху напередодні німецько-радянської війни 1941-1945 років.

Ключові слова: Друга світова війна, Комінтерн, Комуністична партія США, рецесія, тактико - стратегічна модель, Акт Вурхіса.

Питання взаємовідносин між Комуністичною партією США (КП США) та III Інтернаціоналом (Комінтерном), яка знаходилася на периферії інтересів цієї організації протягом серпня 1939 - червня 1941 року, виступає одним зі складових елементів більш широкої проблеми, а саме проблеми впливів, які здійснювали комуністичні партії на функціонування Інтернаціоналу та на зміни в тактико стратегічній моделі. Особливо актуальною дана проблема постає у зв'язку 3 впливом Акту Вурхіса, який став причиною виходу компартії США 3 III Інтернаціоналу.

Таким чином, актуальність статті полягає у розкритті взаємовідносин та взаємовпливів між Комуністичною партією США та III Інтернаціоналом протягом серпня 1939 - червня 1941 року в рамках рецесивної (від лат. recessio - відступ) тактико - стратегічної моделі, аналізі іiі політики та Акту Вурхіса, що став причиною виходу американської компартії з Інтернаціоналу.

Історіографія даної проблеми є значною. Зокрема, питаннями, які стосуються становища Комуністичної партії на території США займалися такі американські дослідники, як Х. Клер [13], Р. Мурхаус [15], В. Кірконелл [12], Г. Льюї [14], Дж. Сімкін [16] та ін. Проблему взаємовідносин між Комуністичною партією США та III Інтернаціоналом в контексті тактико - стратегічної моделі, яка функціонувала в досліджуваний період, аналізували російські історики Н. Лебедєва [2], Ф. Фірсов [6], [7], німецький історик Б. Байєрляйн [1] та ін. Їхні роботи дозволяють виявити характерні особливості, форми зв'язку між III Інтернаціоналом та КП США, сформувати загальну картину їхніх складних взаємовідносин. Проте залишається відкритим питання місця Комуністичної партії США в політиці Комінтерну в досліджуваний період.

Джерельну базу проблеми складають збірники документів Російського державного архіву соціальної та політичної історії (РДАСПІ) [3], [4], [10], тогочасні газетні та журнальні публікації [8], [9], [17], спогади членів компартії США, законодавчі акти США [18], «Шоденник» Г. Димитрова [11]. На особливу увагу заслуговують спогади членів компартії США, матеріали масмедіа, що розкривають вплив, який спричинила зміна зовнішньополітичного курсу Кремля, 
на членів компартії та сприйняття іiї членів та самої компартії американським суспільством. Також, в питаннях змін, які відбувалися в середовищі Комінтерну протягом досліджуваного періоду, інтерес представляють щоденникові записи Г. Димитрова, які розкривають взаємодію Інтернаціоналу 3 Й. Сталіним та радянським керівництвом, а також вплив Акту Вурхіса на Комінтерн.

Таким чином, основне завдання статті випливає 3 актуальності, історіографічної та джерельної бази і передбачає характеристику політики Комуністичної партії США, яка проводилася в досліджуваний період, впливові Акту Вурхіса та аналізі взаємовідносин та взаємовпливів між КП США та Інтернаціоналом в рамках рецесивної тактико - стратегічної моделі протягом серпня 1939 - червня 1941 року.

Політика та взаємовідносини між III Інтернаціоналом та Комуністичною партією США протягом першого етапу Другої світової війни визначалися в рамках тієї тактико - стратегічної моделі, якою керувався Комінтерн при виробленні програмних установок та директивних рішень.

Варто зазначити, що компартія США в даний період не знаходилася в центрі уваги Секретаріату Виконавчого комітету Комуністичного Інтернаціоналу (ВККІ). Основна увага керівництва Інтернаціоналу була зосереджена переважним чином на комуністичних партіях країн Західної Європи, становище яких ускладнилося у зв'язку з підписанням 23 серпня 1939 року пакту Молотова - Ріббентропа та початком 1 вересня Другої світової війни, а також на Комуністичній партії Китаю (КПК) при вироблені політики компартії у ії взаємовідносинах з Чан Кайши.

Проте, варто зауважити, що підписання пакту Молотова-Ріббентропа значно ускладнило становище не лише європейських компартій, але і компартії США, викликавши широку антирадянську та антикомуністичну пропаганду на Заході. Це пояснюється підтримкою компартіями різкого повороту сталінської зовнішньої політики на зближення з нацистською Німеччиною. Проте, не зважаючи на це, як вказує російський історик Н. Лебедєва, компартії підтримали зовнішньополітичний крок Кремля [2, с. 148]. Як зазначає американський дослідник В. Кірконелл, 26 серпня генеральний секретар КП США Е. Браудер через службу радіо NBC щиросердечно схвалив та висловив підтримку пакту, як «найкращого прикладу шляху до миру» [12].

На підтримку пакту про ненапад, журнал «Soviet Russia Today» публікує статтю під назвою «Значення пакту про ненапад». Автори вказують на неспроможність «домінуючих держав» та їхніх лідерів, прем'єр-міністра Великобританії Н. Чемберлена та міністра іноземних справ Франції Ж. Бонне чинити супротив фашистській агресії в Європі; цитують звітну доповідь Й. Сталіна на XVIII з’ізді ВКП(б); акцентують увагу на зростаючій силі Радянського Союзу, його економіки, військових сил та дипломатичної ваги на міжнародній арені та потенційному страху Німеччини перед СРСР. Цим самим автори статті намагаються створити певного роду картину альтернативної реальності, в якій наслідками пакту не фігурують зникнення з політичної карти Польщі та початок війни в Свропі. Стаття закінчується словами: «Мюнхен - це шлях до капітуляції, шлях до війни, до перемоги агресорів та пригноблювачів. Москва - шлях до миру, до звільнення, до перемоги людства» [17]. Це звучить як прелюдія нової тактико стратегічної моделі Комінтерну та натяк на причетність західних демократій, а не Радянського Союзу, до розв'язання нової війни в Свропі. 
Наступного дня, 27 серпня, генеральний секретар ВККІ Г. Димитров направив Й. Сталіну, голові Ради Народних Комісарів В. Молотову та начальнику Управління пропаганди та агітації ЦК ВКП(б) А. Жданову досить суб'єктивну добірку матеріалів щодо позицій, зайнятої компартіями Західної Свропи, а також компартією США. Головною метою цієї добірки було продемонструвати, що компартії рішуче підтримавши підписання пакту та солідаризувавшись 3 діями сталінського керівництва, розцінили його, як вагомий зовнішньополітичний успіх СРСР та внесок у збереження миру, зрив задумів розпалювачів війни, як удар по агресивній політиці А. Гітлера в Східній Європі [3, с. 73-85]. Матеріали обходили увагою повне збентеження та нерозуміння членами компартій того, що відбулося. Того ж дня Г. Димитров та секретар ВККІ Д. Мануїльський листом повідомили Й. Сталіна, що компартії «зайняли правильну позицію по відношенню до радянсько-німецького пакту про ненапад» [10, с. 150].

Як вказує американський історик X. Клер, після підписання пакту ті комуністи в США, котрі прихильно ставилися до президента Ф. Рузвельта протягом другої половини 1930-х років, тепер знову виступали проти нього, як проти одного 3 винуватців війни та іiі розпалювача [13]. Але була і зворотна сторона медалі. Такі члени компартії США, як Д. Мітфорд та їі чоловік Р. Трехафт не погодилися зі зміною політичної лінії. «Я бачила, як партія переключилася після підписання радянсько-німецького пакту 1939 року з пропаганди боротьби проти фашистських держав на засудження «імперіалістичної війни», 3 чим я була не згодна» - згадує у своїх спогадах Д. Мітфорд [16]. Американський дослідник, Дж. Сімкін, наводить спогади одного з членів КП США, Дж. Гейтса, котрий писав: «Ми виключили всіх, хто відмовився погодитися з нашою новою політикою та хто все ще вважав Гітлера головною загрозою. Людей, яких ми ще вчора поважали, як i місіс Рузвельт, тепер таврували. Це була одна 3 характерних рис комуністів сьогодні ми називали їх героями, а завтра могли назвати зрадниками. Але у всьому цьому була наша єдина послідовність, ми підтримували радянську політику, якою б вона не була, а це, в свою чергу, пояснювало таку кількість наших розбіжностей» [16]. Становище, описане Д. Мітфорд та Дж. Гейтсом, було характерним і для європейських компартій, в рядах яких знаходилися люди, які не розуміли того, що відбулося в дійсності. Окрім того, домінуючий в керівництві партією принцип «демократичного централізму», за якого будь-яке прийняте рішення обов'язкове до виконання всіма членами партії без обговорення, залишав відкритим лише два шляхи - або погодитися з політикою партії або бути затаврованим як зрадник та покинути ії лави.

Незважаючи на те, що компартії за вказівкою Комінтерну в цілому «зайняли правильну позицію», останньому не вдалося виробити остаточної та послідовної позиції до моменту німецької агресії проти Польщі та розв'язання Другої світової війни. Не отримавши вказівок, як правильно оцінювати ситуацію, що склалася, компартії продовжували, у відповідності зі старими установками, якими вони керувалися протягом другої половини 1930-х років, від часу скликання VII Конгресу Комінтерну влітку 1935 року, виступати за рішучу протидію фашистським завойовникам, на підтримку ефективних зусиль в боротьбі проти нацистської Німеччини, на захист Польщі, яка стала жертвою іiї агресії.

Так, виступаючи на пленумі ЦК 2-4 вересня 1939 року, генеральний секретар ЦК Комуністичної партії США Е. Браудер закликав до створення «світового 
фронту миру демократичних націй». Висловивши глибоку симпатію до польського народу, Е. Браудер, як вказує російський історик

Н. Лебедєва, заявив, що «вторгнення в Польщу є варварським актом імперіалістичної агресії, що загрожує національній незалежності польського народу». Продовжуючи свій виступ, він вказав, що «це вторгнення знаменує подальше розширення другої імперіалістичної війни та несе загрозу іiі перетворення в світову війну» [2, с. 149]. Певний дуалізм, який присутній у висловлюваннях очільника КП США між підписанням пакту та початком війни пояснюється, з одного боку, не достатнім розумінням того, що відбувається, а 3 іншого боку - необхідністю висловити своє схвалення та підтримку курсу радянського керівництва та готовністю швидко змінити свої погляди.

У ситуації, яка виникла з початком Другої світової війни, перед Комінтерном постала необхідність пояснити комуністичним партіям значення та наслідки, до яких може призвести нова війна та виробити нову тактико - стратегічну модель. Тому варто звернути увагу на процес вироблення нової моделі, при формуванні якої вагому роль зіграли погляди Й. Сталіна та його розуміння широкомасштабного військового конфлікту, який розпочався в Свропі.

5 вересня Г. Димитров у листі А. Жданову повідомив про розробку документу, який має визначити принципову лінію і тактику компартій в умовах нової імперіалістичної війни в Свропі. Проте, зіткнувшись 3 певними складнощами при формуванні нової моделі, Г. Димитров просив про зустріч з Й. Сталіним задля "їхнього подолання <..> та прийняття правильного рішення» [3, с. 88]. На копії листа 8 вересня Г. Димитров зробив помітку: «Розмова з т. Сталіним у присутності тт. Молотова та Жданова відбулася 7.9.39» [6, с.18]. Під час розмови з Г. Димитровим Й. Сталін заявив, що війна ведеться між двома групами капіталістичних країн (бідні та багаті в розумінні колоній, сировини і т. д.) за переділ світу, за світове панування. «Ми не проти, щоб вони добряче побилися та ослабили одне одного. Непогано, якби руками Німеччини було [б] розхитано становище найбагатших капіталістичних країн (особливо Англії). Гітлер, сам цього не розуміючи та не бажаючи, розхитує капіталістичну систему». До війни протиставлення фашизму демократії справді мало місце. «Під час війни між імперіалістичними державами це вже не вірно. Поділ <..> втратив колишній сенс» [11, с. 115]. Комуністи капіталістичних країн повинні були рішуче виступити проти власних урядів, проти війни. Й. Сталін зайняв різко ворожу позицію стосовно Польщі: «Знищення цієї держави в теперішніх умовах означало би на одну буржуазну фашистську державу менше! Що поганого було би, якби в результаті розгрому Польщі ми розповсюдили соціалістичну систему на нові території та населення» [1, с. 132-133], [11, с. 116], [4, с. 779-781].

Характеризуючи позицію Союзу РСР в цій війні та визнаючи, що пакт про ненапад в певній мірі допомагає Німеччині, Й. Сталін мав намір зі своєї сторони наражати учасників конфлікту один на одного. Таким чином, роблячи ставку на затяжну війну між двома групами капіталістичних країн, він відводив для СРСР роль стороннього спостерігача, що отримує свій зиск від війни. Щодо комуністичного руху, Й. Сталін рекомендував зняти лозунг єдиного народного фронту та запропонував підготувати та опублікувати тези Президії ВККІ, сенс яких зводився до наступного: війна ведеться за панування над світом; воюють господарі капіталістичних країн за власні капіталістичні інтереси; ця війна нічого не принесе робочим, трудящим, окрім страждань та поневірянь [11, с. 116]. Й. Сталін закликав 
рішуче виступити проти війни та іiї винуватців, викривати буржуазні уряди країн, які виступили за нейтралітет та підтримували інші держави, які ведуть війну 3 метою наживи [2, с. 150-151], [5, с. 33].

Характеристика Й. Сталіним становища, що склалося вказувала на необхідність кардинальної зміни орієнтирів для компартій. Відкидалася лінія боротьби на захист демократії, проти фашизму як головної небезпеки та джерела агресії, проголошена на VII Конгресі. Компартіям потрібно спрямувати всю пропаганду проти імперіалізму загалом, зняти гасло народного фронту та відмовитися від співпраці з соціал-демократією. Висувалися гасла боротьби проти війни та іiі винуватців - «національних урядів», гасла знищення капіталістичного рабства, проте основна критика була спрямована не проти реального агресора, яким на той час вже виступила Німеччина, а проти західних демократій і жодного слова не говорилося про завдання боротьби з гітлеризмом. На ділі Й. Сталін дав розпорядження Комінтерну та компартіям розвернути фронт боротьби проти демократичних країн Заходу.

Сталінська формула про те, що відмінності між демократичними та фашистськими державами в умовах війни втратили сенс, не враховувала національних інтересів народів, що протистояли фашизму. Війна проти агресора, яким виступала Німеччина, об'єктивно носила антифашистський характер, незалежно від цілей, які переслідували уряди країн, що оголосили їй війну. Сталінська характеристика поточної ситуації розколювала сили, які протистояли Німеччині та призводила до ізоляції компартій. Насправді сталінський режим 3 початку Другої світової війни послідовно виказував підтримку Німеччині, що було логічним, враховуючи договір про ненапад, а також таємні протоколи до нього, 3 якими не було ознайомлене керівництво Комінтерну, позаяк відсутні свідчення подібного роду.

Таким чином, 7 вересня 1939 року була сформована нова головна лінія поведінки комуністичних партій з початком війни в Європі. Бачення Й. Сталіним міжнародної ситуації лягло в основу нової парадигми відносин між СРСР та країнами Заходу, призвівши до ревізії моделі, якою керувався Комінтерн та компартії протягом другої половини 1930-х років. Відбулася рецесія моделі, в ході якої рішення, лозунги та співпраця 3 демократичними урядами та соціалдемократією в рамках рішень VII Конгресу задля забезпечення миру та спокою в Європі відходять у минуле. Політика антифашизму також відходить на другий план. У рамках рецесії моделі кремлівський диктатор намагався сформувати та проштовхнути нову прецесію ворога, розвертаючи фронт боротьби не лише проти війни, але і проти національних урядів. 8 вересня була складена директива за підсумками розмови Г. Димитрова з Й. Сталіним та розіслана компартіям [3, с. 8889].

Протягом кінця серпня - вересня 1939 року припинилася майже вся антифашистська агітація, яку проводила компартія США. 19 вересня газета «Daily Worker» публікує Декларацію Національного Комітету КП США, складену в дусі отриманої з Москви директиви від 8 вересня. Війна у Декларації характеризується як «друга імперіалістична», що ведеться між «конкуруючими імперіалізмами за світове панування». Німецький різновид фашизму, нацизм, визначається, як «кривава диктатура монополістичного капіталу». Основна провина за розв'язання війни покладається на уряд прем'єр-міністра Великобританії Н. Чемберлена, який «роками спекулював на темі німецько-радянської війни». Як вказується у 
Декларації, задля цього Н. Чемберлен «допоміг Гітлеру зміцнити та переозброїти Німеччину», ввести війська в демілітаризовану Рейнську зону; «задля цього він дозволив захопити Австрію; задля цього він пожертвував Чехословаччиною» та ін. Введення Червоної Армії на територію Західної України та Західної Білорусі розцінюється, як справа захисту безпеки кордонів СРСР, а також забезпечення «миру та безпеки народів [Західної України та Західної Білорусії], залишених їхніми колишніми правителями». Польський уряд у Декларації характеризується як «фашистський» (fascist in character) [8, с. 1].

Окрім Декларації, позиція компартії знайшла своє вираження у памфлетах Е. Браудера, наприклад, «Чия це війна?». В них провина покладається на англійців, французів та поляків за розв'язання війни. В той же час Е. Браудер намагається звести до мінімуму будь-яку критику нацистської Німеччини та СРСР. За словами лідера КП США, дії Й. Сталіна та підписання радянсько - німецького договору виявилися абсолютно вірними. Як вказує американський дослідник Р. Мурхаус, посилаючись на памфлети Е. Браудера, Радянський Союз був силою миру, яка зупинила просування нацистів та «врятувала більше половини Польщі», «використала протиріччя між імперіалістами, щоб вони не змогли втілити свої плани пригноблення та війни» [15].

Підтримка зовнішньополітичної лінії Кремля та пакту про ненапад американською компартією призвело до масового виходу з партії. Як вказує американський історик X. Клер, незважаючи на те, що досить багато американців приєдналося до КП США в часи проведення політики антифашизму, (друга половина 1930-х років), позаяк вони підтримували політику та ідеали партії, переважна більшість 3 них швидко відмовилася від партії після крутого повороту, викликаного кардинальною зміною радянської зовнішньої політики до співпраці 3 Німеччиною. Не зважаючи на те, для тих, хто залишився вірним партії, СРСР виступала батьківщиною соціалізму, першою робітничою державою, яку необхідно було захищати від капіталістичного світу [13].

Окрім цього, у жовтні 1939 року Е. Браудера звинуватили в шахрайстві 3 паспортом, після його зізнання, що він здійснював поїздки закордон по фальшивим документам. Не дивлячись на очевидні політичні мотиви справи (Е. Браудер був кандидатом у президенти на виборах 1940 року), йому присудити чотири роки в'язниці, що призвело до його тимчасового зникнення з політичної арени. Е. Браудера буде звільнено тільки після початку війни Німеччини проти СРСР, в 1941 році.

Кампанія компартії з лозунгом «Свободу Ерлу Браудеру» тільки погіршила суспільне невдоволення комуністами та посилила негативне ставлення до пакту Молотова - Ріббентропа. Сам пакт наніс американському комуністичному рухові удар, від якого, на думку американського дослідника Р. Мурхауса, комуністи в США вже не змогли оправитися [15].

Таким чином, під впливом Кремля компартії, за вказівками Комінтерну, кардинально змінили своє розуміння та ставлення до війни. Однак, цей поворот, як вказує російський історик Н. Лебедєва, «дався важко» [2, с. 152]. Нову лінію не одразу прийняли деякі компартії, в тому числі і компартія США. Зважаючи на це, Президія ВККІ на засіданні 19-20 жовтня 1939 року обговорила питання «Про позицію і тактику компартій в умовах імперіалістичної війни». В рішеннях підкреслювалася необхідність «надати системну допомогу компартіям 3 виправлення допущених помилок та встановлення правильної позиції по 
відношенню до війни», а також висувалася вимога «зосередити боротьбу проти опортунізму, що виражався в скочуванні на оборонні позиції, в підтримуванні легенди про антифашистський характер війни та у відступі перед репресіями буржуазії» [3, с. 141-143]. Як вказує американський дослідник Г. Люьї, протягом двох місяців після вступу в силу пакту Молотова - Ріббентропа, КП США повернулася до колишньої та більш агресивної політики [14, с. 173]. Також свідченням переходу до розуміння війни в «сталінському варіанті» слугує цитата 3 газети «Daily Worker», яка охарактеризувала війну, як «сімейну сварку двох імперіалізмів, що змагаються між собою»(«a family quarrel of rival imperialisms») [9, c. 2].

По завершенні формування правильної політичної лінії та ставлення компартій до пакту Молотова-Ріббентропа та війни, в дусі сталінських вказівок Комінтерн почав орієнтувати компартії, а через них i робітничий клас капіталістичних країн на боротьбу проти імперіалістичної війни, за припинення кровопролиття, але без висунення революційних гасел. Це фактично означало протидію військовим зусиллям Англії та Франції, а також підтримку демагогічної кампанії нацистського керівництва та співпрацю 3 агресором. Ці установки, як вказує Н. Лебедєва, визначали характер директив Комінтерну компартіям в кінці 1939 - на початку 1940 року [2, с. 157]. Подібного роду директиви отримувала i компартія США, не зважаючи на те, що основна увага сталінського керівництва та Комінтерну була прикута до європейських компартій. За приклад слугує шифрована радіограма Г. Димитрова в Нью-Йорк Е. Браудеру, відправлена 25 листопада 1939 року. У ній генеральний секретар Комінтерну просив про «енергійну та довготривалу кампанію проти теперішньої реакції у Франції». Характеризуючи Францію як «не демократичну країну», в радіограмі дається вказівка продемонструвати придушення у Франції всіх демократичних свобод: «парламент, комуни, преса, профспілки, заборона зборів, військова диктатура». Французька влада характеризується як «режим, якого ще не знали у Франції, якщо не рахувати переслідувань після Комуни» (мається на увазі Паризька Комуна 1870 року), а голова уряду Е. Даладьє є «звичайним авантюристом гірше Наполеона Третього». Радіограма закінчується вказівкою організовувати «демонстрації протесту, профспілкові маніфестації солідарності та протесту на підтримку профспілок Франції» [1, с. 298].

КП США була частково залучена і до радянсько-фінської війни 1939-1940 року, під час якої становище комуністів США лише ускладнилося. Проте вони продовжували захищати та підтримувати політику СРСР. Виступаючи в ролі слухняного інструменту в руках Й. Сталіна та Політбюро, Комінтерн давав компартіям відповідні вказівки.

На основі архівних матеріалів, російський історик Ф. Фірсов вказує, що в директивах Інтернаціоналу американським компартіям (США, Канада, країни Латинської Америки) вимагалося завадити наданню допомоги Фінляндії під час радянсько-фінської війни. В іншій директиві Секретаріат ВККІ дав вказівку КП США допомогти Міртону (радянський розвідник, справжнє ім'я не встановлено) в його роботі з відбору людей в середовищі фінський комуністів в Америці для відправки до Фінляндії. Уже по закінченню радянсько-фінської війни, як вказує російський історик Ф. Фірсов, європейські компартії, КП США та компартії Латинської Америки, з якими підтримувався зв'язок через компартію США, 
зобов’язувалися виступати на захист «сталінської миролюбної політики, що відповідає інтересам всіх народів» [7, с. 295, 297].

Починаючи з весни 1940 року до кінця 1940 - початку 1941 року американська компартія відходить на другий план через події, які розгортаються в Європі. В цей час Німеччина окуповує Скандинавію (Данія, Норвегія), країни Бенілюксу (Бельгія, Нідерланди та Люксембург), завдає поразки Франції весною 1940 року та входить в Париж. Тому основна увага ВККІ була прикута до компартій окупованих нацистами країн, які змушені були перейти на нелегальне становище. Окремо варто зазначити значну увагу, яку приділяв Комінтерн Французькій комуністичній партії (ФКП), котра влітку 1940 року зробила спробу домовитися 3 окупаційною адміністрацією, щоб налагодити легальний випуск преси, що мало не призвело до компрометації французьких комуністів та арешту паризького осередку ФКП. Ці питання мали більш нагальний характер, що і викликало певний «режим тиші» у відносинах з КП США між весною - кінцем 1940 року.

Наприкінці 1940 - на початку 1941 року керівництво Комінтерну звертає увагу на діяльність компартій Великобританії та США. В резолюції Секретаріату ВККІ Комуністичній партії США, що була прийняла на початку травня 1941 року, на перший план висувалося посилення боротьби «проти демагогії та впливу Рузвельта, проти соціал-демократизму та проти ізоляціонізму», «за припинення війни та встановлення міцного миру». Разом з тим, в документі зазначалося: «Не послаблюючи основних ударів по американській імперіалістичній буржуазії як класові, не послаблюючи роботи проти британського імперіалізму, партія повинна також проводити більш енергійну боротьбу проти німецького та японського імперіалізму» [3, с. 528-535]. Дана теза вказує на те, що Комінтерн переорієнтувався та зайняв більш нейтральну позицію щодо боротьби проти обох воюючих таборів.

Варто вказати, що розширення війни ускладнило умови для розвитку комуністичного руху та поставило компартії в досить різні, але однаково складні, умови. Після ii початку виникли додаткові складнощі для діяльності компартії США в тому числі. В жовтні 1940 року в США був прийнятий Акт про Реєстрацію певних організацій або Акт Дж. Вурхіса. Він передбачав обов'язкову реєстрацію в Міністерстві юстиції будь-якої громадсько-політичної організації, якщо вона ставить собі за мету «скинення уряду Сполучених Штатів» чи «використання насильницьких методів для здійснення контролю над його діяльністю» та діє «під іноземним контролем». До цієї категорії потрапляли всі організації, які прямо чи опосередковано співпрацювали з іноземною державою, політичною партією іншої держави чи міжнародною політичною організацією. Ще однією важливою складовою, яку передбачав Акт Вурхіса, був перелік документів, які необхідно подати під час реєстрації організації. Це ставило під загрозу зв'язок, який підтримувала компартія США 3 Комінтерном та могло призвести до повної заборони компартії на території Сполучених Штатів. Таким чином, за допомогою Акту Вурхіса уряд США намагався встановити максимально широкий контроль за діяльністю організацій, які мали зв'язок з іноземними державами, особливо над компартією США, яку, в процесі прийняття Акту, прямо назвали в числі організація, що підлягають реєстрації [18].

Як вказує Н. Лебедєва, надзвичайний з'їзд компартії в Нью-Йорку, який відбувся в листопаді 1940 року, розглянувши ситуацію, що склалася, прийняв 
рішення, що компартія «анулює свою органічну приналежність до Комуністичного Інтернаціоналу, а також до всіх інших організацій, які існують за межами Сполучених Штатів Америки $з$ тим, щоб не потрапити під дію Акту Вурхіса». Разом 3 цим, з'їзд підтвердив непохитну прихильність КП США «принципам пролетарського інтернаціоналізму в дусі його великих вождів та учителів - Маркса, Енгельса, Леніна, Сталіна, який відкриває страждаючому людству єдиний шлях в майбутнє» [2, с. 181].

Президія ВККІ на початку грудня 1940 року визнала рішення позачергового з’їзу компартії США «політично правильним та доцільним», оскільки воно має перехідний характер та викликано специфічними обставинами, які виникли в країні [3, с. 458-459]. Насправді, КП США повністю залишилася на колишніх позиціях та зберегла засекречені контакти 3 Москвою, проте формально перестала бути секцією Комінтерну.

Цей досить вдалий приклад політичної мімікрії привернув увагу Й. Сталіна, i в квітні 1941 року він підняв питання про ліквідацію Інтернаціоналу. Свою пропозицію «володар Кремля» аргументував необхідністю перетворити компартії в національні партії, що діють під різними назвами. «Важливо, щоб вони проникли у власний народ та концентрували боротьбу на власних завданнях. У них має бути комуністична програма, вони повинні спиратися на марксистський аналіз, але, не оглядаючись на Москву, вирішувати виникаючі конкретні завдання в даній країні самостійно. А становище та завдання в різних країнах суттєво відрізняються» [11, с. 155-156]. Автор поділяе думку російського історика

Н. Лебедєвої, що роздуми Й. Сталіна, буцімто приналежність компартій до Інтернаціоналу заважає їм самостійно розвиватися та вирішувати свої завдання скоріше за все призначалася для загалу. За цією фразою приховувалися особисті політичні розрахунки Й. Сталіна [2, с. 182].

Проте, дане висловлювання «хазяїна Кремля» знайшло своє відображення в діяльності ВККІ, та відповідно, у щоденникових записах Г. Дмитрова. Два дні по тому, 22 квітня, відбулося засідання Американської комісії. Як вказує Г. Димитров, на засіданні було «розроблено завдання для незалежного розвитку та дій комуністичних партій, їхньої роботи та боротьби як національних комуністичних партій своїх країн», а також обговорено наслідки даного кроку для Америки [11, с. 157].

Наступний запис від 12 травня. Цього дня Г. Димитров відвідав ЦК ВКП(б) та зустрівся 3 А. Ждановим. Вони обговорювали питання Комінтерну. «Варто зазначити, що на даному етапі важливо не спрямовувати комуністичний рух в різних країнах з одного міжнародного центру, а приділяти першочергову увагу комуністичному руху в кожній окремій країні, незалежності комуністичних партій, які самі здатні очолити робітничий рух у своїх країнах, розробити власну стратегію, тактику та нести повну відповідальність за робітничий рух у своїх країнах, покладаючись повністю на власні сили», - занотував Г. Димитров.

Окрема увага була приділена питанню об’єднання «правильного поняття націоналізму 3 пролетарським інтернаціоналізмом», де останній мав витікати 3 першого. Посилаючись на Й. Сталіна, Г. Димитров вказує, що «між правильно зрозумілим націоналізмом та пролетарським інтернаціоналізмом не може бути ніяких протиріч. Безрукий космополітизм, - продовжує Г. Димитров, - що відкидає національні почуття та поняття батьківщини, не має нічого спільного 3 пролетарським інтернаціоналізмом». Подальше прочитання запису Г. Димитрова 
вказує на те, наприкінці весни 1941 року існували реальні передумови для розпуску ВККІ та Комінтерну, зміни форм та методів роботи в цілому. «... ВККІ розформується, але міжнародний центр управління продовжить існувати в іншій формі». В окремий підпункт були виділені питання в якій формі відбудеться розпуск ВККІ «...3 власної ініціативи керівництва чи за пропозицією ряду комуністичних партій. Останнє здається краще», записав Г. Димитров.

Запис закінчується перерахуванням моментів при розпуску Комінтерну, які позитивно вплинуть на подальший розвиток комуністичного руху та комуністичних партій в тому числі [10, с. 162-164]. Варто зробити припущення, що якби не напад Німеччини на СРСР 22 червня 1941 року, питання розпуску Комінтерну було б вирішене найближчим часом.

Таким чином, характеризуючи політику Комуністичної партії США та проводячи аналіз іiї взаємовідносин з III Інтернаціоналом, можна зробити наступні висновки: компартія США знаходилася на периферії інтересів Комінтерну в зазначений період, що було викликано ситуацією в Європі та початком Другої світової війни; підписання пакту Молотова - Ріббентропа викликало нерозуміння такого кроку радянського керівництва частиною членів КП США та спричинило вихід 3 компартії значної частини членів; політика, яку проводила компартія США, цілком відповідала тактико - стратегічній моделі, яку виробив Комінтерн під пильним контролем та впливом Й. Сталіна на початку вересня 1939 року; незважаючи на те, що компартія знаходилася на периферії політики Комінтерну, вона була залучена до критики «імперіалістичної війни», демократії та національних урядів, до радянсько-фінської війни 1939-1940 року та захисту СРСР від «імперіалістичної війни» в рамках тактико - стратегічної моделі Інтернаціоналу; під впливом обставин, внутрішньополітичного становища та прийняттям Конгресом США Акту Вурхіса, компартія змушена було «анулювати свою органічну приналежність до III Інтернаціоналу», проте залишилася на тих же позиціях, що і до цього; вихід компартії США з Комінтерну, а також надзвичайне розмаїття становищ, в яких діяли європейські компартії, дало привід Й. Сталіну підняти питання про розпуск даної організації.

Остання теза дає змогу припустити, що тільки напад Німеччини на СРСР не дав «володарю Кремля» розпустити III Інтернаціонал, який продовжив своє існування до 1943 року.

\section{Список використаних джерел та літератури}

1. Байерляйн Б. «Предатель - ты, Сталин!» Коминтерн и коммунистические партии в начале Второй мировой войны (1939 - 1941): утраченая солидарность левых сил / Б. Байерляйн. Москва: Российская политическая энциклопедия (РОССПЭН): Фонд «Президентский центр им. Б.Н. Ельцина», 2011. - 679 с.

2. История Коммунистического Интернационала 1919-1943: Документальные очерки / [Отв. ред. А. О. Чубарьян]; Ин-т всеобщей истории. - Москва: Наука, 2002. - 413 с.

3. Коминтерн и Вторая мировая война. Ч.1: до 22 июня 1941 г. / [Сост. Н.С. Лебедева, М.М. Наринский] - Москва: Памятники исторической мысли, 1994. - 554 с.

4. Политбюро ЦК РКП(б) - ВКП(б) и Коминтерн:1919-1943 гг. Документы. / [Отв. ред. Г. М. Адибеков, К. М. Андерсон, К. К. Шириня] - Москва: «Российская политическая энциклопедия» (РОССПЭН), 2004. - 960c.

5. Смирнов В.П. Французская коммунистическая партия и Коминтерн в 1939-1940 гг. Новые архивные материалы / В. Смирнов // Новая и новейшая история. - 1994. - №1 - - С. 30-46

6. Фирсов Ф. И. Архивы Коминтерна и внешняя политика СССР в 1939-1941 гг. / Ф. Фирсов // Новая и новейшая история. - 1992. - №6. - С. 12-35. 
7. Фирсов Ф.И. Секреты Коммунистического Интернационала. Шифропереписка / Ф. Фирсов. - Москва: Российская политическая энциклопедия (РОССПЭН); Фонд «Президентский центр им. Б.Н. Ельцина», 2011. - 519 с.

8. Daily Worker (газета) 19.09.1939

9. Daily Worker (газета) 06.11.1939

10. Dimitrov and Stalin: 1934-1943. Letters from the Soviet Archives / [ed. by A. Dallin and F.I. Firsov]. - New Haven and London: Yale University Press, 2000. - 278 p.

11. Dimitrov G. The Diary. 1933-1949. / G. Dimitrov. - New Haven and London: Yale University Press, 2003. -497 p.

12. Kirkconnell W. Communism in Canada and the U.S.A. [Electronic Resource] - Mode of Access: http://www.cchahistory.ca/journal/CCHA1947-48/Kirkconnel.pdf (Last Access: 14. 11. 2017). Title from the Screen.

13. Klehr H. American Reds, Soviet Stooges [Electronic Resource] - Mode of Access: https://www.nytimes.com/2017/07/03/opinion/communist-party-usa-soviet-union.html (Last Access: 12. 11. 2017). - Title from the Screen.

14. Lewey G. The Cause That Failed: Communism in American Political Life. / G. Lewey. - New York: Oxford University Press, 1990. - 384 p.

15. Moorhouse R. The Devil's Alliance /R.Moorhouse. - New York: Basic Books, $2014-432$ p. [Electronic Resource] - Mode Access: https://books.google.com.ua/books?id=8yhWDgAAQBAJ\&pg=RA1-PT62\&lpg=RA1-

PT62\&dq=cpusa + in $+1939-$

1941\&source=bl\&ots=3hiBf3Bas9\&sig=u18sFDPCB7J4kBZfS4Z8XJJ2UV8\&hl=ru\&sa=X\&ved=0ahU KEwiGzqOD7b3XAhW1QpoKHb5FAcAQ6AEIJDAG\#v=onepage\&q=cpusa\%20in\%201939-

1941\&f=false (Last Access: 15. 11. 2017). - Title from the Screen.

16. Simkin J. Communist party in the United States [Electronic Resource] - Mode of Access: http://spartacus-educational.com/USAcommunist.htm (Last Access: 12. 11. 2017). - Title from the Screen.

17. The Meaning of the Non-Aggression Pact // Soviet Russia Today. Vol. 8, No. 5 [Electronic Resource] - Mode of Access: http://www.marxisthistory.org/history/usa/parties/cpusa/1939/0900-srtmeaningofpact.pdf (Last Access: 12. 11. 2017). - Title from the Screen.

18. 18 USC 2386: Registration of certain organizations. United Stated Code, Title 18 Part I $\begin{array}{llllll}\text { Chapter } & 115 & \text { [Electronic Resource] } & - & \text { Mode of Access: }\end{array}$ http://uscode.house.gov/view.xhtml?req=granuleid:USC-prelim-title18section2386\&num=0\&edition=prelim (Last Access: 20. 11. 2017). - Title from the Screen.

\section{References}

1. BAYERLEIN, B. (2011) «Predatel' - ty, Stalin!» Komintern i kommunisticheskie partii v nachale Vtoroii myrovoii voiiny (1939 - 1941): utrachenaia solidarnost' levykh sil. Moscow: Rossiiiskaia politicheskaia enciklopediia (ROSSPEN): Fond «Prezidentskiii centr im. B.N. El'cyna»

2. CHUBAR'IAN, A. (ed.) (2002) Istoriia Kommunisticheskoho Internacionala 1919-1943: Dokumental'nye ocherki. Moscow: Nauka.

3. LEBEDEVA, N., NARINSKII, M. (ed.) (1994) Komintern $i$ Vtoraia mirovaia voiina. Ch.1: do 22 iyunia 1941 h. Moscow: Pamiatniki istoricheskoii mysli.

4. ADIBEKOV, H., ANDERSON, K., SHIRINIA, K. (ed.) (2004) Politbyuro $C K R K P(b)-$ $V K P(b)$ i Komintern:1919-1943 hh. Dokumenty. Moscow: «Rossiiskaia politicheskaia enciklopediia» (ROSSPEN).

5. SMIRNOV, V. (1994) Francuzskaia kommunisticheskaia partiia i Komintern v $1939-1940$ hh. Novye arkhivnye materialy. Novaia i noveiishaia istoriia. 1. P. 30-46.

6. FIRSOV, F. (1992) Arkhivy Kominterna i vneshniaia politika SSSR v 1939-1941 hh. Novaia $i$ noveiishaia istoriia. 6. P. 12-35.

7. FIRSOV, F. (2011) Sekrety Kommunisticheskoho Internacionala. Shyfroperepiska. Moscow: Rossiiaskaia politicheskaia encyklopediia (ROSSPEN); Fond «Prezidentskii centr im. B.N. El'cyna».

8. DECLARATION OF THE NATION COMMITTEE, Communist Party of the U.S.A. Daily Worker. 19th September. P. 1.

9. BROWDER, E. (1939) Twenty-Two Years Of Socialism. Daily Worker. $6^{\text {ht }}$ November. P. 2.

10. DALLIN, A., FIRSOV, F. (ed.) (2000) Dimitrov and Stalin: 1934-1943. Letters from the Soviet Archives. New Haven and London: Yale University Press.

11. DIMITROV, G. (2003) The Diary. 1933-1949. New Haven and London: Yale University Press. 
12. KIRKCONNELL, W. Communism in Canada and the U.S.A. Canadian Catholic Historical Association Report $15 . \quad$ p. 41-51. [Online] Available from: http://www.cchahistory.ca/journal/CCHA1947-48/Kirkconnel.pdf [Accessed: 14th November 2017]

13. KLEHR, H. (2017) American Reds, Soviet Stooges [Online] Available from: https://www.nytimes.com/2017/07/03/opinion/communist-party-usa-soviet-union.html [Accessed: 12th November 2017]

14. LEWEY, G. (1990) The Cause That Failed: Communism in American Political Life. New York: Oxford University Press.

15. MOORHOUSE, R. (2014) The Devil's Alliance. [Online] Available from: https://books.google.com.ua/books?id=8yhWDgAAQBAJ\&pg=RA1-PT62\&lpg=RA1-

PT62\&dq=cpusa + in $+1939-$

1941\&source=bl\&ots=3hiBf3Bas9\&sig=u18sFDPCB7J4kBZfS4Z8XJJ2UV8\&hl=ru\&sa=X\&ved=0ahU

KEwiGzqOD7b3XAhW1QpoKHb5FAcAQ6AEIJDAG\#v=onepage\&q=cpusa\%20in\%201939-

$1941 \& \mathrm{f}=$ false [Accessed: 15 th November 2017]

16. SIMKIN, J. Communist party in the United State [Online] Available from: http://spartacuseducational.com/USAcommunist.htm [Accessed: 12th November 2017]

17. The Meaning of the Non-Aggression Pact. Soviet Russia Today. Vol. 8, No. 5. p. 5-6. [Online] Available from: http://www.marxisthistory.org/history/usa/parties/cpusa/1939/0900-srtmeaningofpact.pdf [Accessed: 12th November 2017]

18. 18 USC 2386: Registration of certain organizations. In UNITED STATES CODE, Title 18 Part I Chapter 115 [Online] Available from: http://uscode.house.gov/view.xhtml?req=granuleid:USCprelim-title18-section2386\&num=0\&edition=prelim [Accessed: 20th November 2017]

Надійшла до редколегії 14.03.2018

Ihor Rymar, post-graduate student Mykhailo Drahomanov National Pedagogical University, Kyiv.

\section{THE THIRD INTERNATIONAL AND THE COMMUNIST PARTY OF THE USA: POLITICS AND RELATIONS (AUGUST 1939 - JUNE 1941)}

Abstract. The article describes the policy of the Communist Party of the USA on the basis of documents and monographic literature. The work analyzes the relationship with the Third International within the framework of the recessive tactical - strategic model during August 1939 - June 1941.

The attention is paid to the reaction of the direct participants in the events, first of all, the members of the Communist Party of the USA, to the signing of the Molotov-Ribbentrop Pact on August 23, 1939. The analysis of the attitude of the General Secretary of the Communist Party of the USA E. Browder to both the pact itself and to the foreign policy line pursued by the USSR and the Third International in August 1939 - June 1941.

Being on the periphery of the interests of the Secretariat of the Third International, the Communist Party of the United States supported and defended the thesis of the "imperialist" nature of the war, the involvement of governments, especially Great Britain and France, as well as the administration of $F$. Roosevelt, its continuation and prolongation, development into a world war. Special attention is paid to the position of the US Communist Party to the SovietFinnish war of 1939-1940.

The article analyses the Voorhis Act, its influence on the position of the Communist Party of the United States, and the problem of the existence of the Third International as an organization of the international communist movement on the eve of the German-Soviet war of 1941-1945.

Key words: World War II, Comintern, Communist Party of the USA, recession, tactical strategic model, Voorhis Act. 